Review Scientific Article Received 08.05.2020. Approved 20.07.2020.

\title{
CHALLENGES TO RADICAL INNOVATION WINNING TECHNOLOGY FOR THE CAR OF THE FUTURE? PART TWO
}

\begin{abstract}
This second article on the car for the future investigates the various possible scenarios for a successful innovative solution. An analytical model for innovation is proposed. This new analysis grid makes it possible to evaluate the potential for the emergence of new products, new services, new processes or new organizations, assuming that four conditions must be satisfied simultaneously (same time, same place): "Scientifically and technically possible"; "Industrially feasible"; "Commercially salable"; and "Politically, socially and culturally acceptable". The six key success factors are the followings: Autonomy or driving range; Technological simplicity; Total cost, i.e. purchasing cost and the cost of use; Availability and security of supply, in time and space, of primary energy; Security and reliability; Time scale of deployment of innovations. The specific conditions of the automotive industry are analyzed and discussed in details as well as general economic and political issues impacting positively or negatively the deployment of new innovative automobiles.
\end{abstract}

Keywords: innovation, automobile, electric vehicle, technology management.

* Grenoble Ecole de Management, France and Megatrend University, Serbia; jean-jacques.chanaron-external@grenoble-em.com 
The automotive industry is looking for breakthrough innovations which could contribute to its survival and, if possible, provide it with sustainable competitive advantages. But innovation is an extremely complex process. It has been identified as a critical factor for business development, but remains very difficult to manage when it emerges or needs to be integrated into long-established organizations ${ }^{1}$. The understanding of the directions that it is likely to take implies the use of a model of analysis.

\section{An analytical model}

Many factors or combinations of factors have been advanced by researchers in economics and management to explain the variables that may govern the success or failure of technical and organizational innovations ${ }^{2}$, organizational configuration, including the size of the organization, the cultural context, strategy and leadership, the creativity of human resources. Nevertheless, the understanding of the ideal practices for innovation remains very imperfect ${ }^{3}$ and most scholars postulate that innovation is a fragile and vulnerable activity ${ }^{4}$. Large organizations seem to be unable to innovate sustainably in the long term.

But the main weakness of the academic literature remains its inability to provide decision-makers with an operational model of innovation management. In general, the published models favor a vision of the supply of new ideas by research institutions and businesses and neglect the vision by the demand, and in particular the expectations of the users and/or consumers and their level of acceptance of the technical solutions that are proposed to them.

$1 \quad$ Schumpeter, J.A., (1911): The Theory of Economic Development: An Inquiry Into Profits, Capital, Credit, Interest, and the Business Cycle, Harvard University Press, Cambridge, 1934 edition; Chanaron, J.J., Metcalfe, S.M., (2007), Schumpeter's Innovation Theory, in Carayannis, E., Ziemnowicz C., (2007): Re-Discovering Schumpeter: Creative Destruction Evolving into 'Mode 3', MacMillan-Palgrave, New York, pp. 52-67.

2 Tidd, J., Bessant, J., Pavitt, K., (1997), Managing Innovation: Integrating Technological, Market and Organizational Change, John Wiley \& Sons, London, 3rd edition, 2005: Burgelman, R.A., Christensen, C.M., Wheelwright, S.C., (2004), Management of Technology and Innovation, Irwin Publishers, Chicago; Chanaron, J.J., (1998), Automobiles: a static technology, a « wait-and-see » industry?, International Journal of Technology Management, Vol. 16, $\mathrm{n}^{\circ} 7$, pp.595-630; Carayannis, E.G., Ziemnowicz, C., (2007), Rediscovering Schumpeter: creative destruction evolving into" Mode 3", Palgrave Macmillan, New York.

3 Ahmed P. K., (1998), Benchmarking innovation best practice, Benchmarking for Quality Management \& Technology, 5, 1; pp. 45-56.

4 Dougherty, D., Hardy, C. (1996), Sustained product innovation in large mature organizations: Overcoming innovation-to-organization problems, Academy of Management Journal, 39, 5, pp. 1120-1153. 


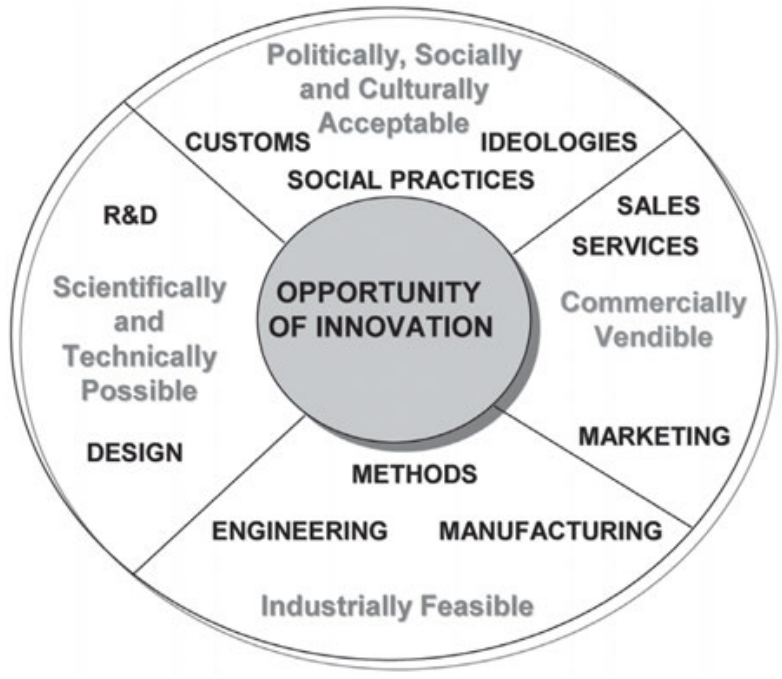

Figure 1. Comprehensive model

A new analysis grid makes it possible to evaluate the potential for the emergence of new products, new services, new processes or new organizations (Figure $1)^{5}$. It assumes that four conditions must be satisfied simultaneously (same time, same place). Any potential innovation must be:

- "Scientifically and technically possible", i.e. meets the expected technical performance of consumers and users;

- "Industrially feasible", i.e. produced at cost and quality levels that satisfy all stakeholders;

- "Commercially salable", i.e. launched at a level of selling price and maintenance costs that are acceptable to the market;

- "Politically, socially and culturally acceptable", i.e. receives the political support and the full acceptance of consumers.

The analytical model advocates that the success of a given innovation is only possible when and if the main variables associated with these four systems are favorable and failure occurs when key conditions of one or more systems do not exist or are not fulfilled.

What is presented in this chapter is based on a qualitative research methodology. Information, data and opinions were collected by a review of theoretical literature and specialized scientific and technical literature: information from traditional automotive stakeholders (manufacturers, equipment manufacturers, university laboratories, and component manufacturers) as well as new player's potentials

5 Chanaron J.J., (2013), Innovation Valuation: Guesswork or Formalized Framework? A Literature Review, in Akhilesh, K.B., (2013), Emerging Dimensions of Technology Management, Springer India, pp. 17-33. 
(energy suppliers, battery manufacturers and fuel cells, hydrogen producers and distributors). This review of the literature made it possible to set up an interview guide which, after having been tested with a limited number of interviewees, was then conducted with executives of automobile manufacturers and suppliers in charge of research and development and product planning and strategy as well as with researchers from leading public laboratories leading innovative automotive projects in charge of advanced components such as batteries, electronic control units and fuel cells. Also interviewed were officials of energy supply companies (electricity, bio fuels, hydrogen). All respondents held decision-making positions in their respective roles: R \& D, strategy, new product development, production planning. More than one hundred interviews were conducted in China, France, Japan, Germany, Italy and the United States on several missions between 2010 and 2016.

Only the technical, economic, social, cultural and political factors that influence the characteristics of technological innovation in the automotive power train have been reviewed and retained. Obviously, a scientifically more robust exercise should consider technology trends for other onboard equipment; changes in consumer behavior, such as mobility choices; new forms of transport organization (people and goods) as well as changes in laws and governance.

\section{Options in competition}

Applied to different technological options, the innovation model provides key elements for the evaluation of technology and scenario building. There is a consensus among interviewees about a general scenario in which the different paradigms would appear successively in time, i.e. when each technological option is possible, feasible, acceptable and salable (Figure 2).

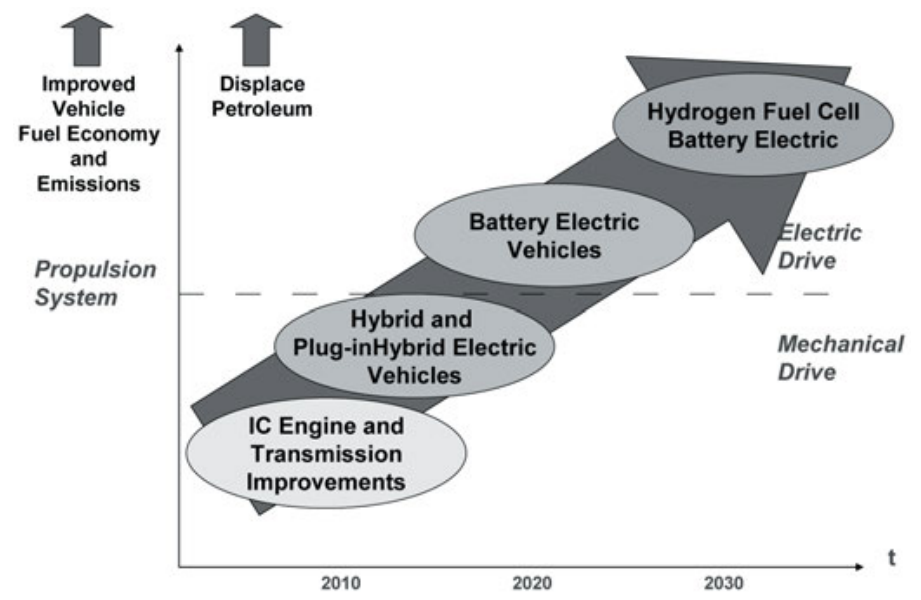

Figure 2. A scenario of consensus 
Since the prerequisites for minimum vehicle performance - size in number of passengers and speed, safety and reliability - are fully met, the six key success factors from the literature review and interviews are the followings:

1. Autonomy or driving range;

2. Technological simplicity;

3. Total cost, i.e. purchasing cost and the cost of use;

4. Availability and security of supply, in time and space, of primary energy;

5. Security and reliability;

6. Time scale of deployment of innovations.

For the automotive industry, the storage of primary energy in the vehicle is one of the key decision-making factors of the customer-users because it determines five fundamental variables: autonomy, duration of recharging-refueling, safety, weight and size of the vehicle and total cost (Table 1).

The autonomy or distance traveled between two recharging-refueling is obviously a key point. There is no consensus on a minimum acceptable level for a conventional vehicle used in urban areas as well as for interurban connections. If the vehicle of the future is a small city car, a relatively limited autonomy might be possible. It is known that in France, for example, in 2008, 65\% of trips are made by car, both as passengers and drivers, for $83 \%$ of the distances traveled with an occupancy rate of 1.4 persons per car. $73 \%$ of "commuters" use a car or motorcycle (according to the latest public survey carried out in France by INSEE). 99\% of trips and $60 \%$ of distances are "local" mobility, i.e. within a radius of $80 \mathrm{~km}$ around their home. Users drive 3.15 daily trips for a total distance of $25.2 \mathrm{~km}$ and $8 \mathrm{~km}$ per trip. In Europe, only 13\% of trips are more than $60 \mathrm{~km}$ long and almost $40-50 \%$ of cars never move more than $150 \mathrm{~km}$. There are obviously large differences between urbanized areas and large agglomerations and rural areas where the car is almost omnipresent for lack of alternative offer.

Most trips are local and depend on spatial interaction criteria closely related to the organization of space and the place of employment, shopping and other equipment in relation to the place of residence. Theoretically it means that an electric car with reduced autonomy, lower than 100-150 km per recharge, could then satisfy almost all the daily needs of consumers. Of course, there is still a need for long-distance inter-city travel, which concerns a small percentage of customers. An often-advanced solution is the so-called multi-motorization: a small urban car and a "big" family car per household. But, for the moment, customer preference is for a "universal" vehicle rather than for several specialized vehicles per household.

One of the key features of the automotive market is that any alternative product will inevitably be calibrated to the performances of the current dominant design 
The time scale is another crucial dimension. Customers are never ready to switch from one technology to another in a few years. There are approximately 1.5 billion vehicles in circulation in 2017 , of which $72 \%$ are passenger cars. In 2017, the new annual registrations, which renew the fleet, are of the order of 90 million vehicles including 79 million passenger cars and analysts predicted 105 million in 2020 including 85 million cars. Unfortunately, the covid-19 pandemic crisis starting early in 2020 did put a dramatic end to such a trend.

Table 1. Comparing energy storage options

\begin{tabular}{|l|c|c|c|c|c|c|c|c|}
\hline & Unit & Gasoline & Diesel & $\begin{array}{c}\text { Electric- } \\
\text { ity }\end{array}$ & $\begin{array}{c}\text { Natural } \\
\text { Gaz }\end{array}$ & LNG & $\begin{array}{c}\text { Com- } \\
\text { pressed } \mathbf{H}^{2}\end{array}$ & $\begin{array}{c}\text { Liquified } \\
\mathbf{H}^{\mathbf{2}}\end{array}$ \\
\hline State & & Liquid & Liquid & Chemical & Gaz & Liquid & Gaz & Liquid \\
\hline Temperature & Centigrade & Ambient & Ambient & Ambient & Ambient & Ambient & Ambient & $-253^{\circ}$ \\
\hline Pressure & Bars & 1 & 1 & 1 & $>200$ & $5-25$ & $350-700$ & 5 \\
\hline Mass energy & $\mathrm{Wh} / \mathrm{kg}$ & 11900 & 11800 & $100-270$ & 2200 & 7080 & 1200 & $500-1000$ \\
\hline $\begin{array}{l}\text { Volume } \\
\text { energy }\end{array}$ & $\mathrm{Wh} / 1$ & 8900 & 9900 & $250-620$ & 2500 & 4300 & 450 & 1800 \\
\hline $\begin{array}{l}\text { Recharging- } \\
\text { refueling time }\end{array}$ & Minutes & 5 & 5 & $>30-480$ & 5 & 5 & 5 & 5 \\
\hline $\begin{array}{l}\text { Efficiency } \\
\text { tank to wheel }\end{array}$ & $\%$ & $30-35$ & $40-42$ & 72 & $20-38$ & $30-35$ & $\sim 50$ & $\sim 30-35$ \\
\hline $\begin{array}{l}\text { Weight for 60 } \\
\text { litres }\end{array}$ & $\mathrm{Kg}$ & 45 & 50 & $270-600$ & 70 & 36 & $90-100$ & $100-200$ \\
\hline Autonomy & $\mathrm{Km}$ & $\sim 900$ & $\sim 1000$ & $250-500$ & 160 & 430 & $200-300$ & $\sim 180$ \\
\hline
\end{tabular}

Sources : Syrota, 2008 and press cutting.

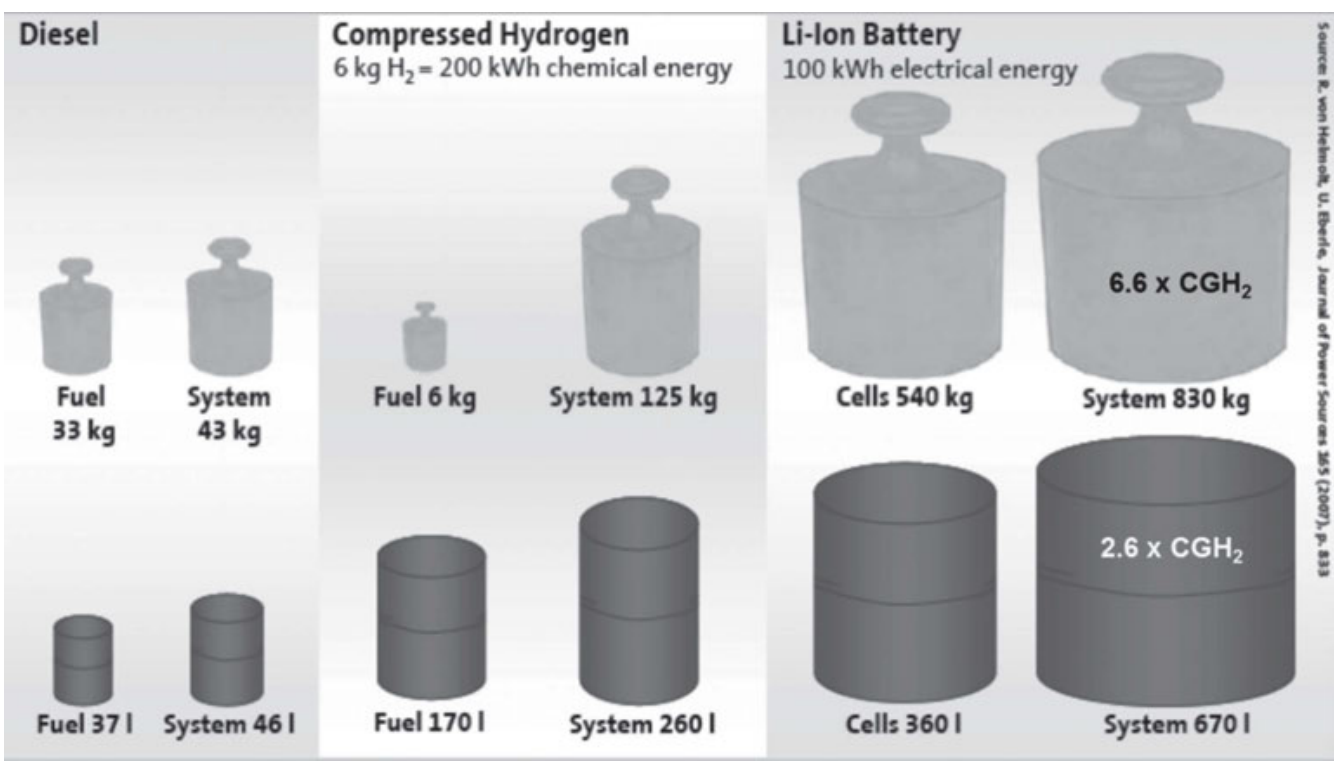

Figure 3. Comparison of storage densities for $500 \mathrm{~km}$ 
It is very difficult to beat fossil fuels in terms of volume and on-board weight. These are certainly not definitive criteria, but one can imagine that consumers will look twice before switching to an alternative option. According to industry experts, park renewal should take at least 15 years. But these estimates are made with unchanged technology. New technology should follow the traditional cycle for any new product, namely an S-curve with a relatively slow take-off to large volumes, which will likely take several decades.

The total cost will inevitably be a decisive criterion. The cost of energy comes first. If the price of oil exceeds sustainably US $\$ 200$ per barrel and then continues to grow, as many experts might predict, it becomes a strong incentive to research for an alternative traction chain and then a massive spread would be possible. But in the current state of technology and given the price of gasoline in 2018, under pressure to stability, or even down with the emergence of shale gas, all alternative solutions will prove more expensive. Rechargeable hybrid or all-electric battery solutions will have to face a recharge cost that could increase with the development of a dedicated infrastructure of charging stations and the deployment of national electricity grids that will have to be upgraded dramatically to support the fast and simultaneous charging of millions of vehicles. As for the cost of replacing batteries at the end of their life, it could also prove to be high.

In 2008, it was estimated that the rechargeable HEV could be a viable solution if gasoline was priced at more than US $\$ 6$ per gallon in the United States ${ }^{6}$. At its highest in 2008, it was US \$ 4 and just over US \$2.54 at the beginning of 2018 .

Many authors have recently looked at the different comparative advantages of battery or hydrogen vehicles and conventional vehicles in terms of consumption, pollution, life cycle, total cost without being able to determine a loser or a winner when facing so many, complex and variable assumptions to be implemented. The most "serious" i.e. scientifically-based studies published by researchers in public laboratories favor "well to wheel" analyzes of energy and environmental efficiency ${ }^{7}$.

They take into account the local conditions of the energy mix. In fact, for electricity generation, countries are not equal (Figure 4): for example, China, with $72.8 \%$ of fossil electricity production, $68.6 \%$ for coal alone and hundreds of

$6 \quad$ Williams E., (2008), Plug-in and Regular Hybrids: A National and Regional Comparison of Costs and CO2 Emissions, Climate Change Policy Partnership, Duke University, November.

See Aguire B., Eisenhardt L., Lim C., Nelson B., Norring A., Slowik P., Tu N ., (2012). Lifecycle Analysis Comparison of a Battery Electric Vehicle and a Conventional Gasoline Vehicle, California Air Resources Board, June;Cai Z., Ou X., Zhang Q., Zhang X., (2012), Full lifetime cost analysis of battery, plug-in hybrid and FCEVs in China in the near future, Frontiers in Energy, 6, 2, pp. 107-111;McCullough R. (2012).Are Electric Vehicles Actually Cost-Effective, Electricity Policy.com, pp. 1-10; Alexander M., Davis M., (2013), Total Cost of Ownership Model for Current Plug-In Electric Vehicles, EPRI Technical Report. Jun M.; Di Muro (2013). Holistic Methodology to Analyze EV Business Models, International Journal of Innovation, Management and Technology, 4, 2, pp. 259-264. 
operating thermal power plants, and Germany, where coal and lignite account for $38.9 \%$ of electricity production, are the worst placed.

In France, the situation is opposed with a clear domination of the nuclear power. But it is Canada and Norway that are the best placed countries in the environmental field thanks to a significant share of hydro-electric power.

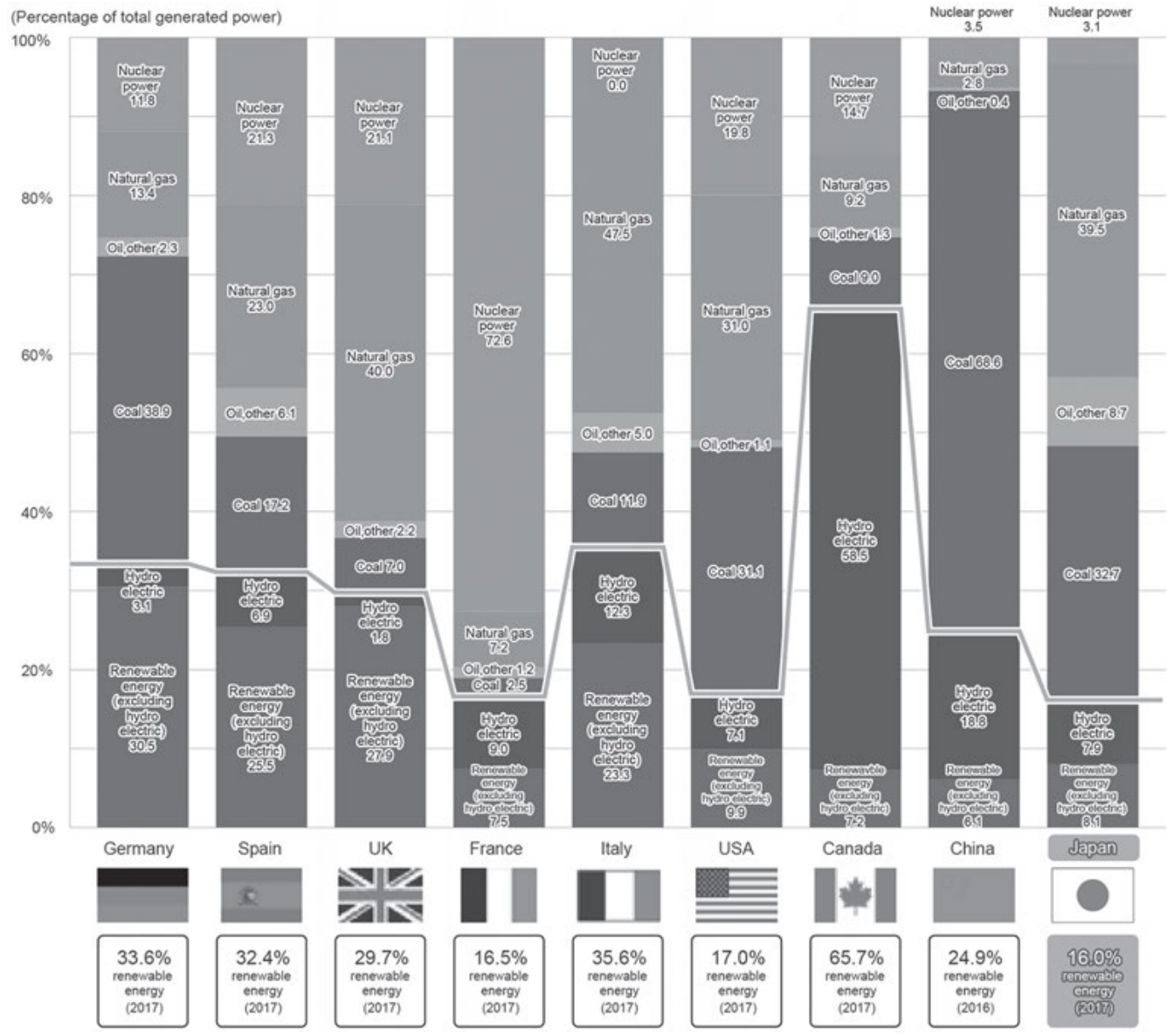

Source: https://www.enecho.meti.go.jp/en/category/special/article/energyissue2019_02.html

Figure 4. Energy mix for electricity in 2019

Technological simplicity is a more complex factor because it is strongly linked to socio-psychological determinants. According to surveys conducted in Europe and the United States, customers seem to have a preference for a monotechnology when deciding on a car power traction chain. This criterion is obviously associated with the technical reliability, which determines the durability and cost of maintenance-repair, and safety of both driving and energy supply. The presence of a vast network of service stations for petroleum fuels gives them 
a strong advantage. It will be necessary for the electric alternatives to guarantee comparable performances.

In behavioral terms, the initial feedback from the owners of Renault Zoe and Twizy tend to show a satisfaction rate of $98 \%$, mainly due to the absence of noise and ease of driving, which is far higher level than those registered in the past for new innovative models. And the vast majority says they would never go back to the internal combustion technology!

While the environmental performance of a given power train is not yet a true decision-making criterion, most industry experts believe that environmentalist sentiments might become stronger and more widely spread in the future. In any case, it is necessary to differentiate the performance of the vehicle not only at the moment of use, or instantaneous performance, but with a well to the wheel perspective and in this regard, partially or fully electric solutions must be evaluated in a transparent manner. Indeed, everything depends on the energy "mix" of the electricity production. In some countries, such as China, the United States and Germany, which still use a lot of coal, rechargeable hybrids and battery-powered vehicles, have higher $\mathrm{CO} 2$ emissions than conventional vehicles.

In countries where the share of nuclear energy is high, electric vehicles and plug-in hybrids are obviously efficient. But it should be emphasized that the shift from a significant part of the fleet to all-electric vehicles with batteries poses the problem of the capacity of the electrical networks, not only in voltage and therefore in section of the low-voltage lines, but also, above all, in production capacity. For example, it is estimated that a fleet of 3 million electric vehicles would require in France one additional Evolutionary Pressurized Reactor (EPR) and 6 to $7 \mathrm{EPR}$ for electrification of the entire fleet. Oppositions to nuclear energy such as the cost and time of construction of such equipment are serious obstacles to such a scenario.

\section{The automotive industry}

What lessons can be learned from a comprehensive scan of the technical documentation and a hundred in-depth interviews with executives in charge of the product strategy and R \& D of manufacturers (Toyota, GM, Chrysler, Nissan, Renault, Peugeot -Citroën, Daimler-Benz, BMW, Fiat, Hyundai, Kia), large public and private research laboratories, specialized non-profit professional organizations, transportation companies and public administrations for environment protection as well as innovative components manufacturers (batteries, fuel cells, electronic control units) in China, Japan, Europe and the United States?

The research is qualitative, investigating a common phenomenon in a reallife context in order to retain the holistic and significant characteristics of real 
life events ${ }^{8}$. As part of the analysis of technology and innovation, it is the expression of a set of opinions and is obviously not scientifically suitable for generalization because it is not based on recognized technology forecasting method such as Delphi, scenario development or probabilistic forecasting.

A first conclusion is the broad consensus among respondents that the competition between the all-electric vehicle and the dominant design of the internal combustion engine (ICE) is still far from being played on the following five factors: energy consumption, autonomy, $\mathrm{CO} 2$ emissions, purchase price and user costs (Figure 5).

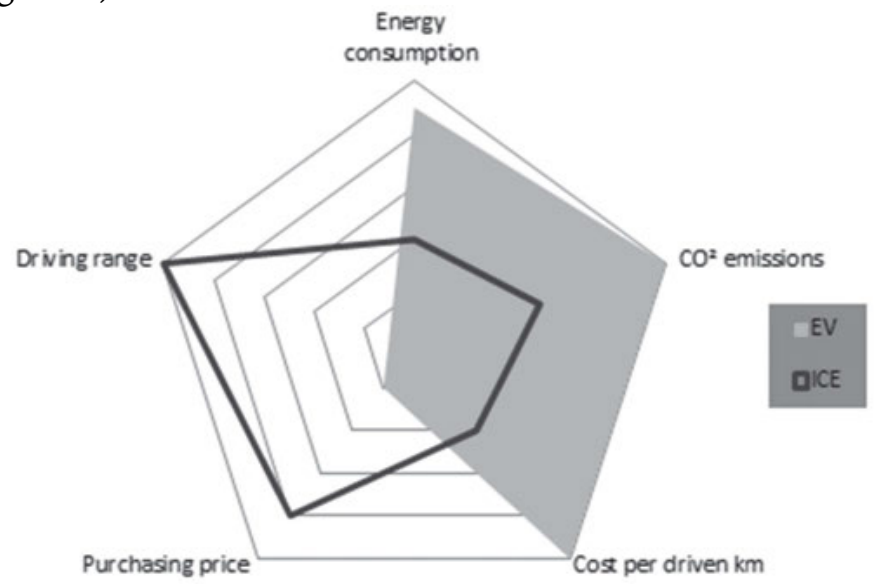

Figure 5. Comparative advantages between Electric and ICE vehicles

Technical as well as behavioral factors can move the electric car towards a more acceptable range. Political factors such as subsidies as well as increased volumes can play a role in changing the purchase price in the right direction. But other factors can give back to the conventional engine some colors in terms of user costs: a lower price and a guaranteed availability in petroleum products or significant advances in terms of depollution and energy consumption.

Forty years after a first research conducted in 1972-1973 on automotive innovation, we must remain cautious and moderately optimistic ${ }^{9}$. The resilience of this industry is remarkable. Global demand is growing fueled by the renewal of fleets but also by the accession to automobiles in emerging countries (Figure 6). Over a long period, it gives no sign of a lasting reversal. And the motorization needs of developing countries are enormous (Figure 7).

$\overline{8} \quad$ Yin R, (2008), Case study research: Design and methods (3rd ed.). Beverly Hills, CA: Sage Publishing

9 Chanaron J.J., (1973), L'innovation dans la construction automobile, Thèse de doctorat, IPEPS/IREP, Grenoble, novembre. 


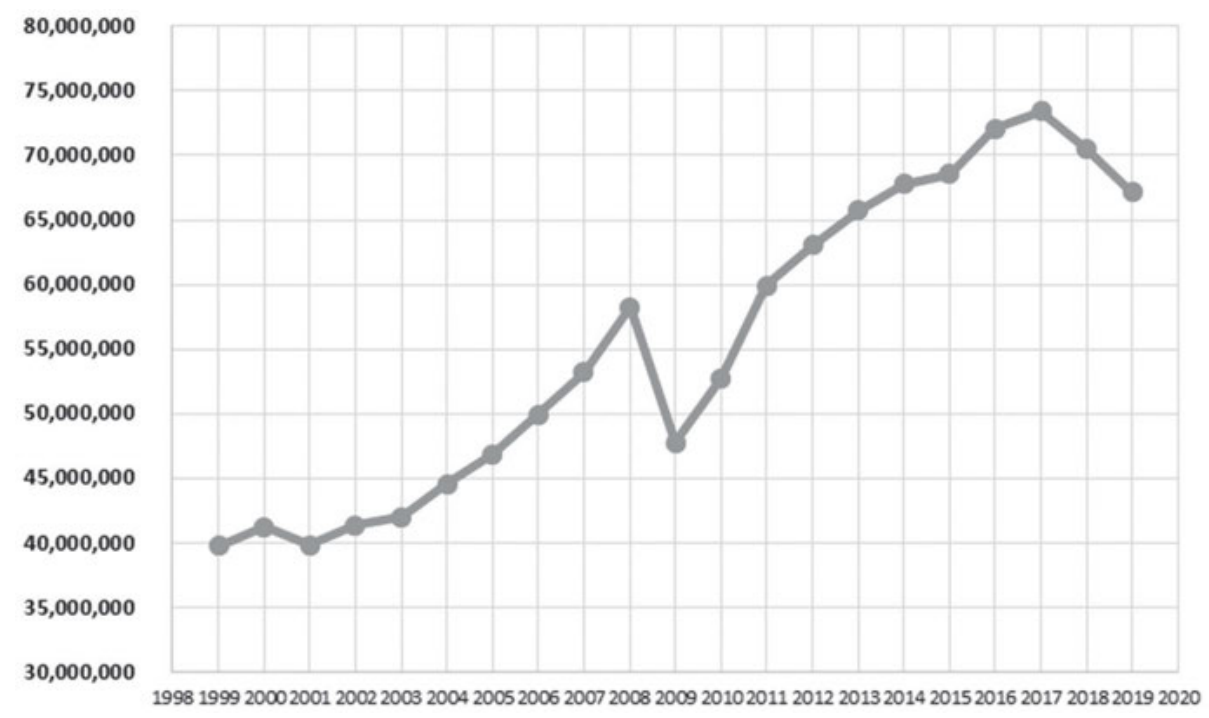

Figure 6. Worldwide production of passenger cars, 1999-2019

The automotive industry, in its current configuration, is a real system that involves many interrelated activities, although they may sometimes have conflicting interests: final assembly, components and equipment, trade and repair, trailer bodies and caravans, production and fuel distribution, road construction and maintenance, public administration, road transport, insurance and financing, sports and press, among others ${ }^{10}$. In France, about $10 \%$ of the active population is directly or indirectly dependent on the system!

It is a mature industry with technologies perfectly mastered and still perfectible in terms of energy consumption and pollution, where knowledge and know-how are difficult to acquire without going through the major traditional stakeholders, mainly the OEMs. This industry has also gigantic fixed industrial investments which are, at least for the moment, unavoidable and managed by iconic corporations, in limited numbers worldwide and unwilling to let "new entrants" threaten their current positions, already abused by their own competitive game. Finally, this industry is totally "path-dependent" vis-à-vis the dominant technology and does not have generally speaking a good command of alternative technologies that are not the result of the metal-mechanical technical system that made their fortune in the last hundred years ${ }^{11}$. In such a context, it is not surprising to observe that technology takes many years to evolve, not only because of its complexity but also because of the resilience of the players.

\footnotetext{
10 de Banville E., Chanaron J.J., (1985), Le système automobile français : de la sous-traitance au partenariat? Eléments pour une problématique, CPE .Etude, $\mathrm{n}^{\circ} 56$, mai.

11 Chanaron J.J., Bye P., (1995), Technology Trajectories and Strategies, International Journal of Technology Management, 10, 1, pp. 45-66.
} 


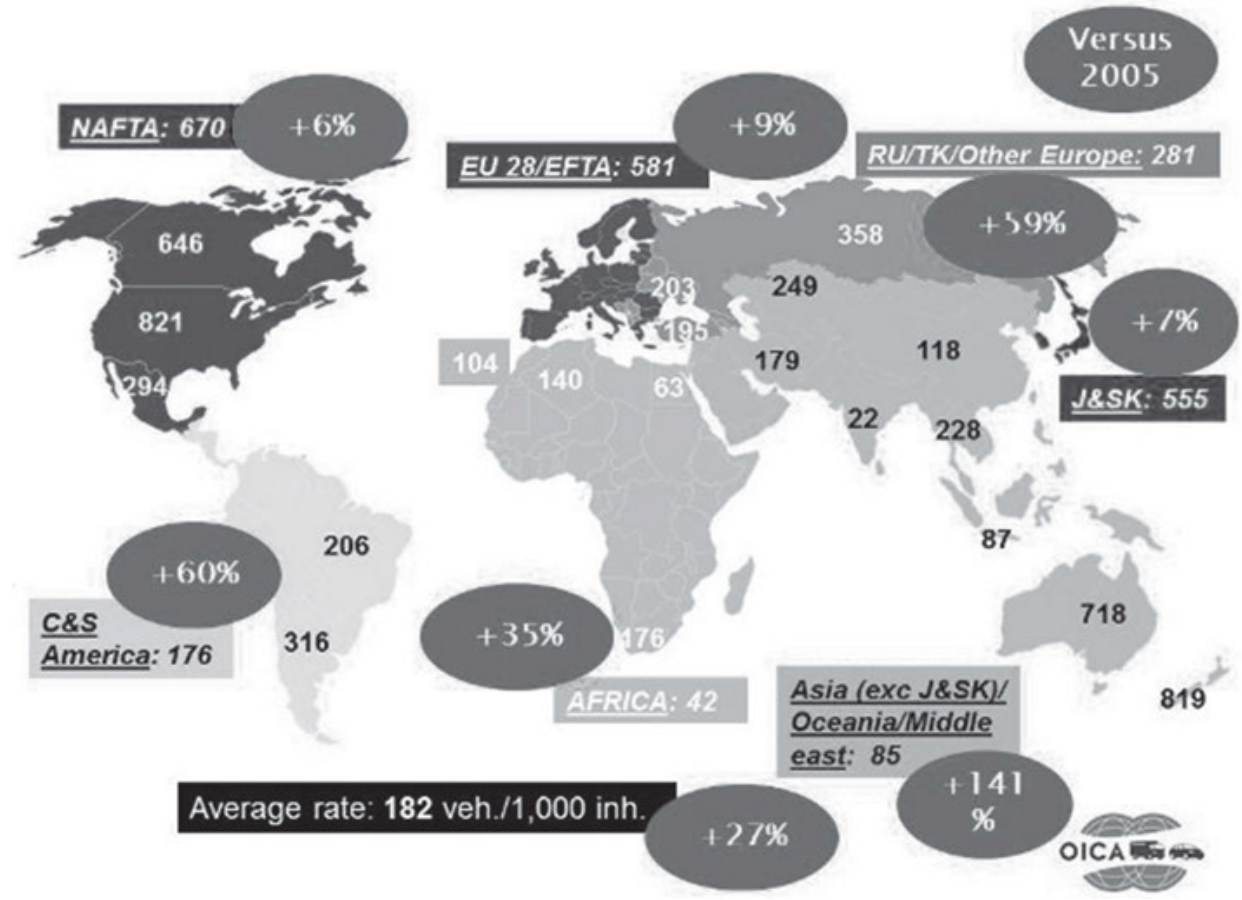

Figure 7. Motorization rate in 2015

The automobile system is a powerful economic policy tool not only in developed countries such as China, USA, Japan, Germany, Italy, South Korea, Brazil and others, by the direct and indirect jobs concerned but generally in all countries through tax revenues related to the acquisition and use of vehicles (Figure 7). The game of lobbies speaks by itself in this respect: Germany, the country with the strongest ecological feeling, but also the booming automotive industry (Volkswagen, BMW, Daimler-Benz) is one of the few countries that have not yet introduced an attractive tax incentive system for clean cars. The German government is probably waiting for its national OEMs to give it the green light in order to avoid that their French and Japanese competitors take a significant market share and appear as innovators and more ecologists!

\subsection{Complex economic issues}

However, one of the decisive factors should be and remain for a long time of economic nature: the purchasing price of the new vehicle and its total cost of use are crucial for potential buyers. And, in this regard, it is obviously the market that holds the keys. Consumers will inevitably compare the new offered electric models to the vehicles available today. 
According to the Argus annual survey, the average new car in 2018was priced $€ 26,000$ for a standard average fuel consumption of 4.7 liters per $100 \mathrm{~km}$ and $113 \mathrm{~g}$ of CO2. In 2016, the breakdown by price rangeis shown in figure 8 :

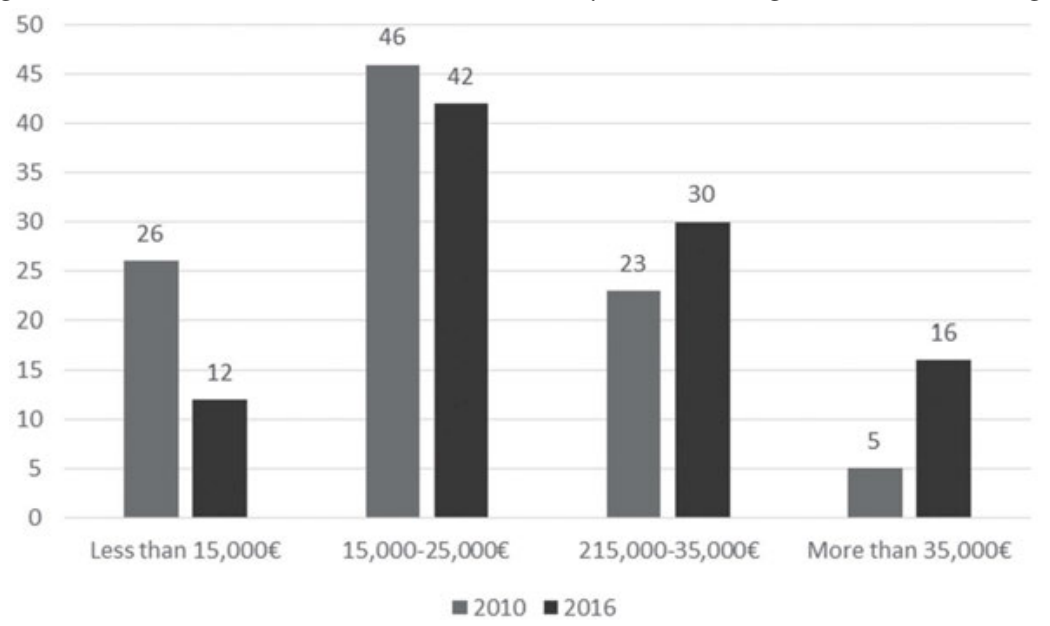

Source : L'Argus $N^{\circ} 4506-13$ avril 2017.

Figure 8. Sales of new cars in France per price level in 2010 and 2016

Table 2 presents information on driving range and price for selected electric cars in France. One can see that as soon as autonomy exceeds $300 \mathrm{~km}$, the market price becomes significantly dearer than the average price of an equivalent ICE vehicle.

Table 2. Information on driving range and price for selected electric cars in France in 2019

\begin{tabular}{|l|c|c|c|}
\hline Model & OEM's official range & Price & Battery rental rate \\
\hline Audi e-tron & $300 \mathrm{~km}$ & $70,000 €$ & \\
\hline BMW i3 & $300 \mathrm{~km}$ & $32,100 €$ & \\
\hline Bolloré Bluecar & $250 \mathrm{~km}$ & $18,300 €$ & \\
\hline Citroën C-Zero & $160 \mathrm{~km}$ & $27,000 €$ & Optional \\
\hline Nissan Leaf & $385 \mathrm{~km}$ & $43,700 €$ & \\
\hline Hyundai Ioniq & $290 \mathrm{~km}$ & $37,000 €$ & \\
\hline Kia Soul EV & $452 \mathrm{~km}$ & $41,300 €$ & \\
\hline $\begin{array}{l}\text { Mitsubishi i-MiEV } \\
\text { electriQ }\end{array}$ & $160 \mathrm{~km}$ & $23,500 €$ & \\
\hline Opel Corsa-e & $335 \mathrm{~km}$ & $29,900 €$ & \\
\hline Peugeot ion & $160 \mathrm{~km}$ & $27,000 €$ & Optional \\
\hline Peugeot 308 & $340 \mathrm{~km}$ & $32,100 €$ & \\
\hline Renault Kangoo ZE & $270 \mathrm{~km}$ & $22,000 €$ & \\
\hline
\end{tabular}

Vol. 17, № 3, 2020: 1-30 


\begin{tabular}{|l|c|c|c|}
\hline Renault Zoé (1) & $400 \mathrm{~km}$ & $26,000 €$ & $69-119 € /$ month \\
\hline Renault Twizy & $120 \mathrm{~km}$ & $7,400 €$ & \\
\hline $\begin{array}{l}\text { Smart ForTwo } \\
\text { Electric Drive }\end{array}$ & $140 \mathrm{~km}$ & $23,000 €$ & \\
\hline $\begin{array}{l}\text { Tesla Model S } \\
\text { standard }\end{array}$ & $615 \mathrm{~km}$ & $85,800 €$ & \\
\hline Tesla Model X & $500 \mathrm{~km}$ & $104,300 €$ & \\
\hline Tesla Model 3 & $560 \mathrm{~km}$ & $59,000 €$ & \\
\hline Volkswagen ID3 & $420 \mathrm{~km}$ & N.C. & \\
\hline $\begin{array}{l}\text { (1) Battery rental } \\
\text { excluded }\end{array}$ & & & \\
\hline
\end{tabular}

Source: http://www.automobile-propre.com/

According to European OEMs, electric vehicles might reach a range of 600 kilometers by 2025-2026 but batteries should be of the same size and weight than those currently available (2020) while costing less.

Table 3 Information on driving range and price for selected electric cars in China in 2018

\begin{tabular}{|l|c|c|c|}
\hline OEM/Model & OEM official range & Price in RMB & Pricein euro \\
\hline BJEV EV 200 & $245 \mathrm{~km}$ & $¥ 208,900$ & $€ 26,611$ \\
\hline BJEV EU 260 & $260 \mathrm{~km}$ & $¥ 205,900$ & $€ 26,229$ \\
\hline BYD e6 & $300 \mathrm{~km}$ & $¥ 309,800$ & $€ 39,465$ \\
\hline Zotye YUN100S & $150 \mathrm{~km}$ & $¥ 108,800$ & $€ 13,860$ \\
\hline Chery eQ & $200 \mathrm{~km}$ & $¥ 169,900$ & $€ 21,643$ \\
\hline BYD e5 & $305 \mathrm{~km}$ & $¥ 195,900$ & $€ 24,955$ \\
\hline Geely DIHAO EV & $235 \mathrm{~km}$ & $¥ 195,800$ & $€ 24,942$ \\
\hline Zotye E200 & $220 \mathrm{~km}$ & $¥ 181,800$ & $€ 23,159$ \\
\hline ZD D1 & $160 \mathrm{~km}$ & $¥ 158,800$ & $€ 20,226$ \\
\hline BYD Qin EV & $300 \mathrm{~km}$ & $¥ 235,900$ & $€ 30,047$ \\
\hline Roewe eRX5 & $270 \mathrm{~km}$ & $¥ 265,900$ & $€ 33,867$ \\
\hline ZD D2 & $155 \mathrm{~km}$ & $¥ 151,800$ & $€ 19,334$ \\
\hline
\end{tabular}

Source: http://www.diandong.com/zixun/2017010547184.shtml http://green.xcar.com.cn/newcar/5_0_27_0_0/ https://ev.autohome.com.cn/?pvareaid=2023985

Other factors of economic nature, which determine the purchasing price and the user cost of electric vehicles and their likely evolution, have been previously mentioned: the price of raw materials, both those entering in the manufacturing process and those necessary for the use of vehicles: lithium, cobalt, platinum, crude oil, electricity. But also other metals (Figure 9): 


\section{Surging Demand}

Projections for key metals in EV batteries (thousand metric tons)

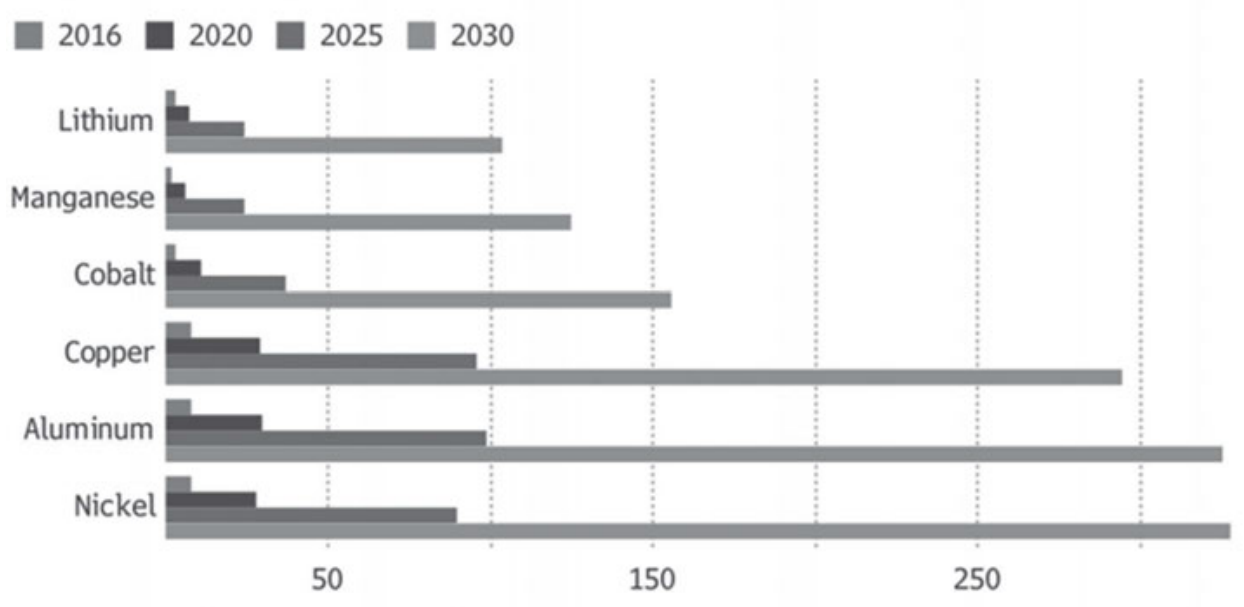

Source: Bloomberg New Energy Finance

Bloomberg

Figure 9. Bloomberg Forecast for Key Metals in Batteries

The price of batteries is, with the autonomy and the number of recharges, a crucial element for the future of rechargeable vehicles. And this price should gradually decrease with the entry into production of giant factories, like that of Tesla, in partnership with Panasonic, in Nevada at a cost of 5 billion dollars. When the site will run at full capacity in 2020, it will produce the equivalent of 32 gigawatts per hour and equip 500,000 cars a year. Similarly, Northvolt, created by Peter Carlsson, a former Tesla Purchasing Manager, is building a giant plant in Sweden that is scheduled to start in the second half of 2018 for gradual commissioning between 2020 and 2023. At full capacity, the site will also produce 32 giga watt/hour per year of lithium-ion batteries.

The gradual reduction of costs and therefore of selling prices is initiated. Experts talk already about "low cost" electric cars: the Renault-Nissan Alliance announced in August 2017 the creation of a joint venture in China with its local partner Dongfeng to develop electric vehicles, for an opening in 2020 with a plant in Shiyan (Hubei Province) and a capacity of 120,000 vehicles per year. The eGT joint venture will be owned $25 \%$ by Renault, $25 \%$ by Nissan and $50 \%$ by Dongfeng, the second largest Chinese manufacturer. The price will be in the range of $\$ 7,000$ to $\$ 8,000$ thanks to the use of the Renault Kwid platform produced in India. The model will also be produced and marketed in India, a country that appears, with China, one of the favorite places of OEMs for such innovative projects. Similarly, Toyota and Suzuki joined forces in November 2017 to launch electric vehicles in the Indian market by $2020^{12}$.

12 Challenge, $21 / 11 / 2017$;

Vol. 17, № 3, 2020: 1-30 


\section{Getting Competitive}

Battery prices seen reaching key level of $\$ 100$ per kilowatt hour by 2026

Actual lithium-ion prices BNEF projections

$\$ 1,000 / \mathrm{kWh}$

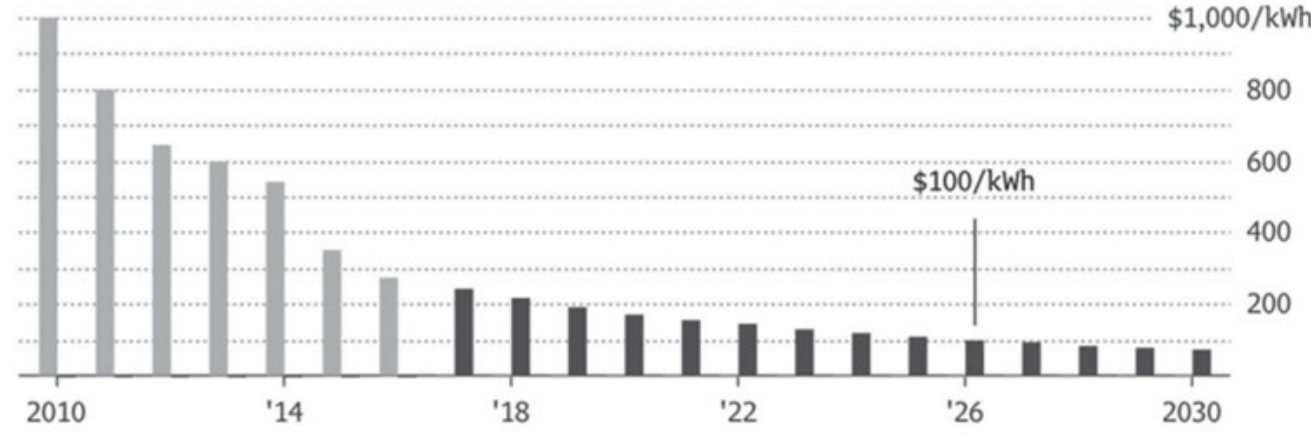

Source: Bloomberg New Energy Finance

Bloomberg

Figure 10. Bloomberg Forecast of Battery Process

It is obviously difficult to estimate the total cost of ownership of an electric car because of the too small size of the existing fleet and the lack of hindsight and experience. Such a limited knowledge does not prevent lobbyists such as the BEUC, the European Bureau of Consumer Unions (http://www.beuc.eu/ publications/), to predict that the average total cost of ownership of a four-yearold electric car could match that of a gas-powered car by 2024. Supreme consecration, electric power might become even cheaper than a diesel before 2030 (Figure 11).

As with gasoline or diesel cars, the consumption of electric vehicles varies by model and by manufacturer. It is measured in "kilowatt hours per hundred kilometers". However, it is difficult to determine the cost of a "full electric", i.e. the recharge of a battery, because the price per kWh may vary depending on the supplier and the consumption of the vehicle depends its autonomy, the capacity of its battery and the driving style adopted.

According to various specialized websites (automobilepropre.com, energuide.be, engie.fr), the cost in electricity for 100 kilometers remains largely below $3 €$. It must of course be taken into account that batteries are also to be considered as a 'consumable' element of the vehicle, in addition to electricity.

From a consumption of an electric car that averages between 12 and 20 $\mathrm{kWh} / 100 \mathrm{~km}$, and multiplying by the rate per kilowatt hour of the energy supplier, a median value of $0.146 € / \mathrm{kWh}$ in full hours and $0.125 € / \mathrm{kWh}$ off-peak at the beginning of 2018, we reach the following indicative values for a home recharge (http://www.automobilepropre.com): 
Table 4. Recharging rates in France as in 2018

\begin{tabular}{|c|c|c|}
\cline { 2 - 3 } \multicolumn{1}{c|}{} & High peak hours & Low peak hours \\
\hline $12 \mathrm{kWh} / 100 \mathrm{~km}$ & $1.75 € / 100 \mathrm{~km}$ & $1.5 € / 100 \mathrm{~km}$ \\
\hline $15 \mathrm{kWh} / 100 \mathrm{~km}$ & $2.20 € / 100 \mathrm{~km}$ & $1.9 € / 100 \mathrm{~km}$ \\
\hline $20 \mathrm{kWh} / 100 \mathrm{~km}$ & $2.90 € / 100 \mathrm{~km}$ & $2.5 € / 100 \mathrm{~km}$ \\
\hline
\end{tabular}

For a recharging at commercial terminals on the public domain, the prices are generally fixed per minute of charge. This is why Corri-Door's quick charge, managed by Sodetrel, a subsidiary of the EDF group, with the support of the European Commission, (200 tri-standard speed terminals installed at the end of 2017), charges from 0.5 to $0.7 €$ the 5 minutes charge. CNR, the network run by the Compagnie Nationale du Rhône, offers a flat rate of 5 euros for a 45-minute charge on $50 \mathrm{~kW}$ tri-standard speed terminals. In France, the price of Tesla superchargers is set at $€ 0.20 / \mathrm{kWh}$ beyond the annual credit allocated by the company to each owner.

\section{4-year TCO}

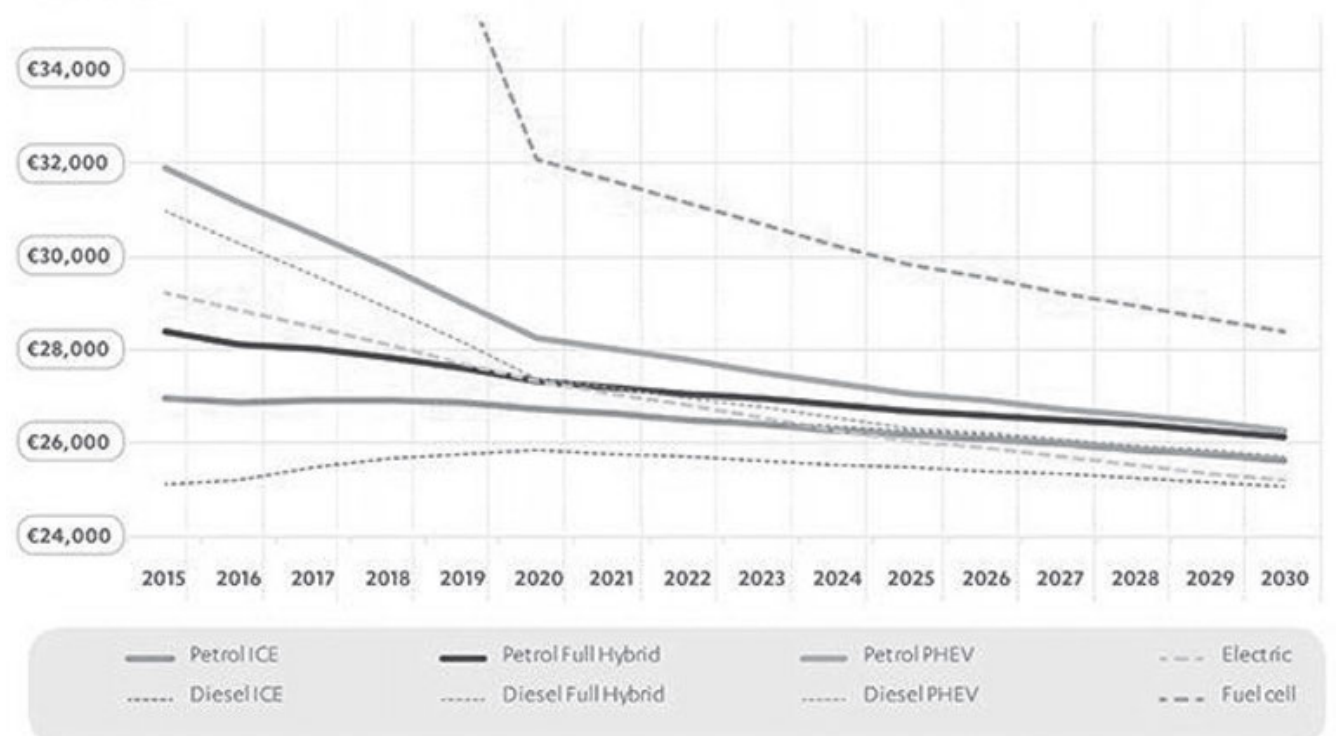

Source: BEUC, (2016).

Figure 11. Change in the average costs of all vehicle types between 2015 and 2030

\subsection{An avalanche of projects}

All major global manufacturers are currently competing for ambitious electricity plans, under the pressure of increasingly restrictive environmental standards and increasing political pressure, particularly in Europe and Asia. In 
addition, they must be forgiven for the many scandals related to cheating on the pollutant emissions of their diesel vehicles that have plagued the entire automotive industry since the fall of 2015 following the revelation of Volkswagen's "dieselgate" with the installation of a software for passing standards during emission tests. More recently, early 2018, Fiat, Ford, and Bosch were accused of similar cheating but in the end all manufacturers are to be suspected of minimizing the pollution of diesel engines: Mercedes Benz, Peugeot, Renault, etc. Showing their voluntarism towards electric vehicles could turn out to be just a strategy of communication: automobile manufacturers prefer to highlight politically correct zero emission vehicles.

The US OEM Ford announced in January 2018 that it would increase its investment in electric vehicles to $\$ 11$ billion by 2022 , while it planned so far 4.5 billion until 2020. The goal is to offer 40 electrified vehicles by 2022, 16 of which are powered by an electric motor, with the balance being gasoline-electric hybrids.

In the US, the number one General Motors (GM) has, for its part, announced in October 2017 an offensive in the electric range, with the launch of twenty allelectric vehicles by 2023, including two new models by 2019 .

Volkswagen is aiming for some 30 electric models in the middle of the next decade, which would weigh 20 to $25 \%$ of the global volumes of the German group at this time. In China alone, Volkswagen is expecting to sell 400,000 electric vehicles per year by 2020 !

In 2017-2018, Daimler Benz is investing 500 million euros in a second lithium-ion battery plant in Germany to power the ten full electric models that Mercedes intends to market by 2025 , from mini-Smart to big $4 \times 4$ SUV. The electric option should then represent about $20 \%$ of sales of Mercedes.

And even the luxury sports car expert, Porsche is launching its electric car range with its so-called Mission E Cross Turismo introduced by Oliver Blume, the CEO of Porsche during the motor show in Geneva early March 2018 which is supposed to compete with Tesla (Challenge, 08/04/2018). The model will be equipped with two electric motors offering more than 600 horse power allowing the car to reach $100 \mathrm{~km} / \mathrm{h}$ in less than 3.5 seconds, exactly like the legendary Porsche 911 GT3 RS today! The promised range would be 500 kilometers and the OEM also promised that $80 \%$ of such autonomy would be recharged in 15 minutes.

The fight against Tesla is also open by Jaguar, which already launched the SUV I-Pace with two motors as well and 400HP for a minimum of 78,000 Euros. At the end of 2018, Audi will commercialize a big luxury SUV inspired by the concept car e-Tron Quattro in 2015 with 435HPand three motors for around 85,000 Euros

PSA is also preparing a new generation of electric models for 2019. These models will be based on a common platform for all future small cars of the group. By 2021, the French manufacturer plans to launch four electric vehicles and plans to sell 40,000 to 50,000 units in China by 2019-2020. 
Amazing phenomenon in a highly oligopolistic industry, the niche is of interest to new entrants: this is how Google, the giant of the Internet, presented the first Google Car it has designed in 2014, a model that does not require any driver, with a very sketchy design for carrying two passengers. The project has been renamed Alphabet and then integrated in the Waymo project.

Like Tesla, General Motors and others around the world, Google is currently targeting the autonomous car market. But all predictions for public launching failed. Most issues are actually much trickier than they sound, as for example even the simple parts of driving, like tracking the objects around a car on the road. Google's sister company Waymo is the clear leader ${ }^{13}$. Waymo just announced 20 million miles driven overall, most of those not in California. In 2018, Waymo drove 1.2 million miles in California, with 0.09 disengagements (moments when a human driver has to take over because the computer could not handle a situation) every 1,000 miles. Coming in second is General Motors' Cruise, with about half a million miles and 0.19 disengagements per 1,000 miles.

Through the "Titan" project launched in 2014, Apple intended to launch an electric car on the roads in 2019 but the Cupertino (California) giant has since changed the project's focus which has shifted to developing self-driving car software instead of an actual car. Physical car project is possibly still in the works plan.

Is it a simple game of competition between giants of the Californian computing industry and car manufacturers?

Dyson, the inventor of the bag-less vacuum cleaner, but also the fan without propellers, wanted also to launch an electric car by 2020 and has planned to invest 2.3 billion euros for its initiative. But on October $10^{\text {th }}, 2019$, Dyson published the following dramatic official statement: "The Dyson Automotive team have developed a fantastic car...but we simply cannot make it commercially viable...We have been through a serious process to find a buyer for the project which has, unfortunately, been unsuccessful so far...The Dyson Board has therefore taken the very difficult decision to propose the closure of our automotive

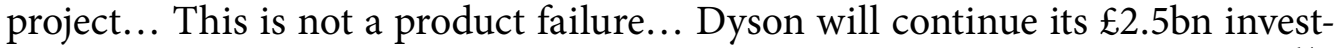
ment program into new technology and grow our wonderful new University." ${ }^{14}$.

The moral of this story is that it is not so easy to become a car manufacturer from scratch! This lesson should be learnt by many others potential new comers.

\subsection{Governments role}

Governments obviously have a major role to play in initiating and expanding the electric vehicle market. China announced on September 28, 2017 that electric vehicle quotas will come into effect in 2019, one year behind schedule.

\footnotetext{
13 See https://www.vox.com/future-perfect/2020/2/14/21063487/self-driving-cars-autonomous-vehicles-waymo-cruise-uber.

14 See https://www.dyson.com/automotive.html.
} 
Rechargeable electric and hybrid vehicles will have to account for $10 \%$ of new car sales in 2019, $12 \%$ in 2020 and $20 \%$ in 2025 . The Chinese government has waived the $8 \%$ quota for 2018 , which was previously considered. He announced to study when could be enacted a ban on motor vehicles that France and Great Britain, for instance, decided to ban in 2040.

Officially, the Chinese government has two goals: to reduce pollution in major cities and reduce its dependence on imported oil by ensuring its energy independence. But it is more than likely that the Chinese government pursues through these measures a third objective, which has nothing to do with ecology: that of promoting the emergence of a national electric vehicle industry. Strongly encouraged by the central government in Beijing, Chinese manufacturers have already taken the lead, holding $96 \%$ of the electric segment, against just a little over $40 \%$ for the entire automotive market. In electric motors but also batteries, a significant part of the global capacity is already located in China.

The political and administrative support of the Chinese authorities to their national champions is obvious. It is the government that builds the bulk of the network of public charging stations and at forced march: nearly 150,000 at the end of 2016, 214,000 early 2018. China also plans to implement about 500,000 additional terminals in the next two years. There are also 232,000 private charging stations in early $2018^{15}$. Building on the success of its models in the Chinese market, Tesla is also in the game: the American firm has installed in Beijing and Shanghai its three largest charging stations. Each station is able to recharge 50 vehicles at the same time and in 30 minutes.

Financial incentives to consumers are also a weapon handled by the Chinese authorities: $\$ 15,000$ is thus offered by the central government and municipal authorities of major cities, making China the most generous state after Norway. In China, electric cars benefit very easily from a license plate in large cities, while for thermal vehicles, the granting of plates is drastically controlled and restricted to fight against pollution and traffic congestion.

In France, the public authorities encourage the shift from ICE vehicles, in particular through a super-bonus of 6,000 Euros for the purchase of a zero pollution model for a car priced less than $€ 45,000$ and $€ 3,000$ for a car priced between $€ 45,000$ and $€ 60,000$. The bonus for vehicles above $€ 60,000$ is limited to commercial vehicles and hydrogen powered cars.

The French state - except the army, police and gendarmerie - as well as its public administrations will now have to buy $50 \%$ of their fleet with "lowemission" vehicles. These models should emit less than 60 grams of CO2 per kilometer. However, only electric and plug-in hybrids fall into this category. The proportion will be $20 \%$ for local authorities, their administrations and public companies. From 2020, taxis, VTC and car rental companies will also have to spend $10 \%$ of their fleet with electric vehicles.

See https://www.breezecar.com. 
In Germany, state aid is limited 4,000 Euros for a full electric vehicle. But the German OEMs have announced in 2017 scrapping premiums for the scrapping of old diesels in favor of a new car, especially electric ${ }^{16}$. Volkswagen Group offers from 2,000 Euros to 10,000 Euros, depending on the range level of the desired model, for the scrapping of a diesel Euro 1 to Euro 4 and the order of a new car: it is estimated at 5,000 Euros the premium for a Volkswagen Golf, but only 2,380 Euros when buying its full electric variants (in addition to the government bonus), 1,785 Euros for a hybrid and 1,000 Euros for a natural gas engine. Mercedes-Benz is offering 2,000 Euros for the purchase of a gasoline-electric rechargeable vehicle and 1,000 Euros for the purchase of a 100\% electric Smart For two.

It is obvious that the windfall effect explains the growth rates of the electric car market. As soon as the public authorities relax their aid, as in France where the premium bonus was decreased from 10,000 to 6,000 Euros, growth has slowed down significantly! In fact, without a premium, subsidy or any other financial incentive, the market would not take off. This is a confirmation that a technology that must be accompanied by public support is in fact not mature, or in others terms still not really accepted by the market and able to compete with the technology it is supposed to replace!

\subsection{Social acceptance}

The electric car raises a lot of questions, particularly about the welcome that consumers-users will give to it. Market research is most often biased and reliable results are extremely rare as it is difficult to estimate values in anticipation of a technology still in its infancy.

The study conducted in 2010 by students from the Ecole Supérieure de Commerce in Paris and Cap Gemini with a population of 754 people with the official quotas set by INSEE, resulted in interesting results (Figure 12). The respondents believe that they would be willing to buy an electric car provided it is not more expensive than a thermal car.

According to the study, the minimum speed accepted is $132 \mathrm{~km} / \mathrm{h}$ on average and the minimum autonomy of $232 \mathrm{~km}$ on average, the sample being ready to sacrifice speed more than autonomy. But the cost criterion remains discriminating.

An Accenture study in $2011^{17}$, conducted in 13 countries with more than 7,000 people, notes that the issue of autonomy also teases potential buyers since $61 \%$ would buy an electric car if its battery allowed a course equivalent to that of an ICE car tank refueling. Government aid seems not to convince them: only $32 \%$ of respondents would be pushed to buy by such aid.

\footnotetext{
16 Challenge, 09/08/2017.

17 La tribune, $25 / 05 / 2011$.
} 


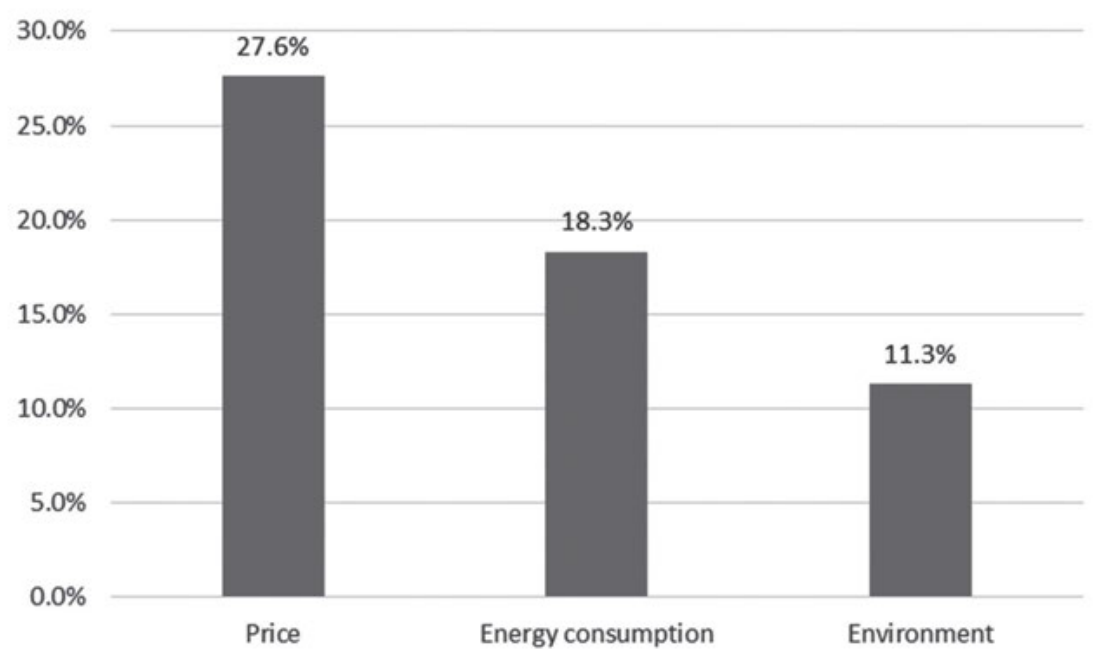

Source : ESCP (2010).

Figure 12. Purchasing factors of an electric vehicle

The consulting company OC\&C published similar data regarding obstacles to the purchase of an EV in 2019 in France where surprisingly 46\% of the respondents declared they are "interested" in buying an electric car far ahead of Germans (23\%), British and Americans (19\%). Only Chinese respondents are ahead of French consumers: 73\%.

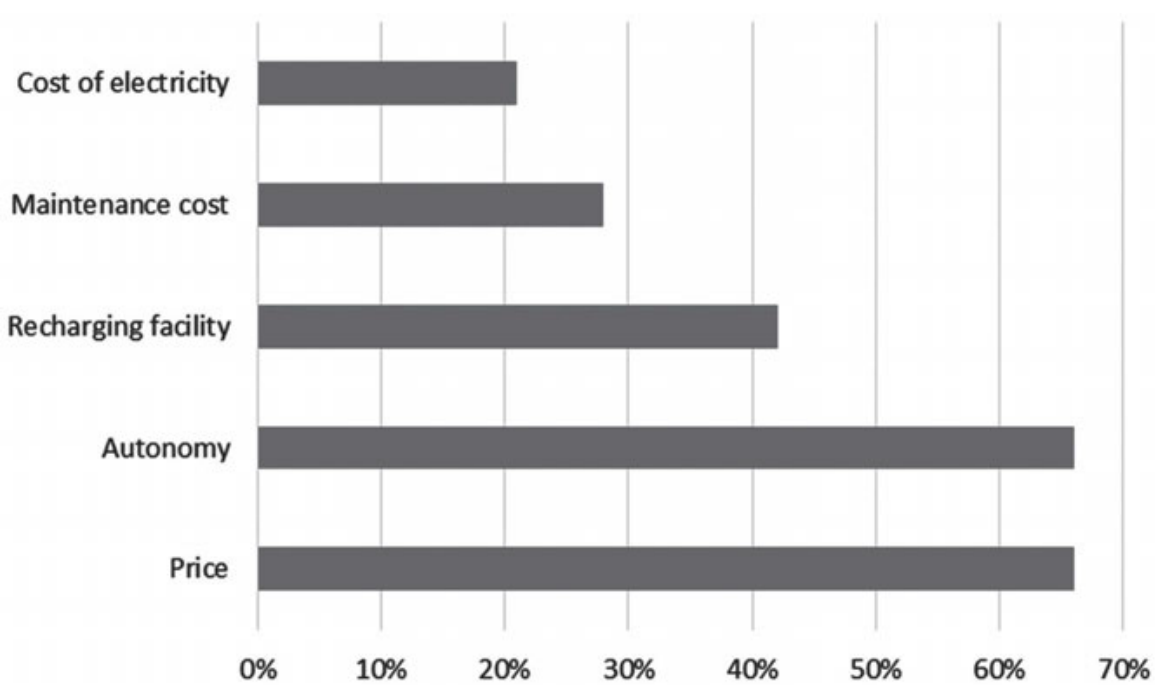

Source: OC\&C, in Capital, 12/12/2019.

Figure 13. Obstacles to the purchase of an electric car 
In general, owners of electric cars are more lenient ${ }^{18}$. It is also shown that dissatisfaction is linked to limited autonomy and to the weakness of the recharging system, which can make it impossible to travel more than the basic autonomy of the car, such as holidays or trips or long business trips different from usual journeys, or a trip to a destination without a charging system. Users then mention the obligation to own in parallel an ICE vehicle. The users of electric cars note the absence of rolling noise both as a clear advantage but also as a source of danger.

It is also the main result of several university researches in the United States. For example, an investigation in the Minneapolis-Saint-Paul region shows that the acquisition of an electric car is as much linked to the autonomy - estimated at $240-320 \mathrm{~km}$ - as to the household's travel needs and the availability of alternative means of transport, including a second internal combustion engine vehicle ${ }^{19}$.

A study conducted in China among 458 consumers and published in 2018 shows that $35.8 \%$ of respondents do not wish to acquire an electric car, $46.1 \%$ want to buy an EV as second vehicle and only $18.1 \%$ to replace an ICE vehicle ${ }^{20}$. Autonomy is by far the crucial factor, largely in front of battery life, but consumers also cite as very important the quality and reliability of batteries as well as the availability of charging stations.

KPMG has been conducting an annual survey of thousands of senior executives in the automotive and consumer industries for nearly twenty years on industry trends. In the latest version released early 2018, we see that the option electric car, battery or hydrogen, is not very popular! Thus, $55 \%$ of the 1,500 executives of the automotive industry interviewed believe that the battery-powered vehicle option will never be able to prevail, as the challenge of building the required infrastructure is enormous. Ranking the challenges in descending order, the executives surveyed put costs (30\%), infrastructure (28\%), environmental constraints (25\%) and ecological footprint (18\%) at the top. As for the consumers (more than 2,500 questioned), they also rank at the top the costs $(35 \%)$, the recharge (28\%), the autonomy (12\%), the technological uncertainties $(11 \%)$ and the interest for daily use (10\%).

Charging time is a crucial criterion for the majority: $51 \%$ of consumers and even $60 \%$ of executives believe that the charging time for an electric car should be similar to the time of a refueling today, in other words a few minutes!

18 Poupon, L., Philipps-Bertin, C., Bobillier-Chaumont, M.E., Kalampalikis, N. (2017), L'acceptation de la voiture électrique : un agent transformateur des pratiques socio-domestiques, Activites, 14, 2, pp. 1-25.

19 Tamor, M.A., Gearhart, C., Soto, C., (2013), A statistical approach to estimating acceptance of electric vehicles and electrification of personal transportation, Transportation Research Part C, 26, pp. 125-134; Tamor, M.A., Moraal, P.E., Reprogle, B., Milacic, M., (2015), Rapid estimation of electric vehicle acceptance using a general description of driving patterns, Transportation Research Part C, 51, pp. 136-148.

20 Wang, N., Tang, L., Pan, H., (2018), Analysis of public acceptance of electric vehicles: An empirical study in Shanghai, Technological Forecasting \& Social Change, 126, pp. 284-291. 
Autonomy is everywhere reported as the most important factor. This is how Auto Foresight, a Chinese consulting firm, estimates that $400 \mathrm{~km}$ is the minimum acceptable ${ }^{21}$. But it is also shown that in fact, the real needs of users, measured in terms of average daily mileage - about $35 \mathrm{~km}$ in the United States, but also in France - are far below the desired or expected autonomy and that, in in other words, current offers could satisfy the vast majority of travel needs ${ }^{22}$.

Table 5. Range of daily shuttles in France in 2016

\begin{tabular}{|l|c|c|}
\hline \multirow{2}{*}{} & \multicolumn{2}{c|}{ Distance in kilometers } \\
\cline { 2 - 3 } & \multicolumn{2}{|c|}{ Average } \\
\hline Intra-municipal shuttles included & 23.6 & Median \\
\hline Urban poles & 30.5 & 13.8 \\
\hline Peri-urban areas & 28.4 & 10.2 \\
\hline Rural areas & 25.9 & 7.9 \\
\hline All areas & 34.3 & 9.7 \\
\hline Intra-municipal shuttles excluded & 35.1 & 15.6 \\
\hline Urban poles & 40.2 & 17.4 \\
\hline Peri-urban areas & 35.4 & 12.2 \\
\hline Rural areas & \multicolumn{2}{|c|}{} \\
\hline All areas &
\end{tabular}

Source : INSEE.

It has been suggested ${ }^{23}$ a very concise and interesting model of barriers to adoption of electric vehicles (Figure 14).

It is obviously difficult, if not impossible, to conclude on a scenario that inevitably imposes itself. Automotive manufacturers, as well as politicians, administrations and all other stakeholders, are far from a consensus on a "one-best-way".

Obviously, if the performance of lithium-ion batteries were to reach the levels expected by the research laboratories that would allow a range greater than $1,600 \mathrm{~km}$, the scenario in favor of battery vehicles would see its probability singularly increased. But even if that would be the case, many problems will still have to be resolved, such as the depletion of lithium reserves, the recycling of

\footnotetext{
$21 \quad$ Financial Times, 24/10/2017.

22 Pearre, N.S., Kempton, W., Guensler, R.L., Elango, V.V., (2011), Electric vehicles: How much range is required for a day's driving?, Transportation Research Part C, 19, pp. 1171-1184.

23 Berkeley, N., Bailey, D., Jones, A., Jarvis, D., (2017), Assessing the transition towards Battery Electric Vehicles: A Multi-Level Perspective on drivers of, and barriers to, take up, Transportation Research Part A, 106, pp 320-332.
} 
batteries, the power supply of charging stations and plugs, and the postponement of global warming towards production of primary energy, etc.

It will also be unavoidable to compete with other technologies, such as petroleum or natural gas engines and, of course, hydrogen, which many experts consider to be the energy source of the 21st century.

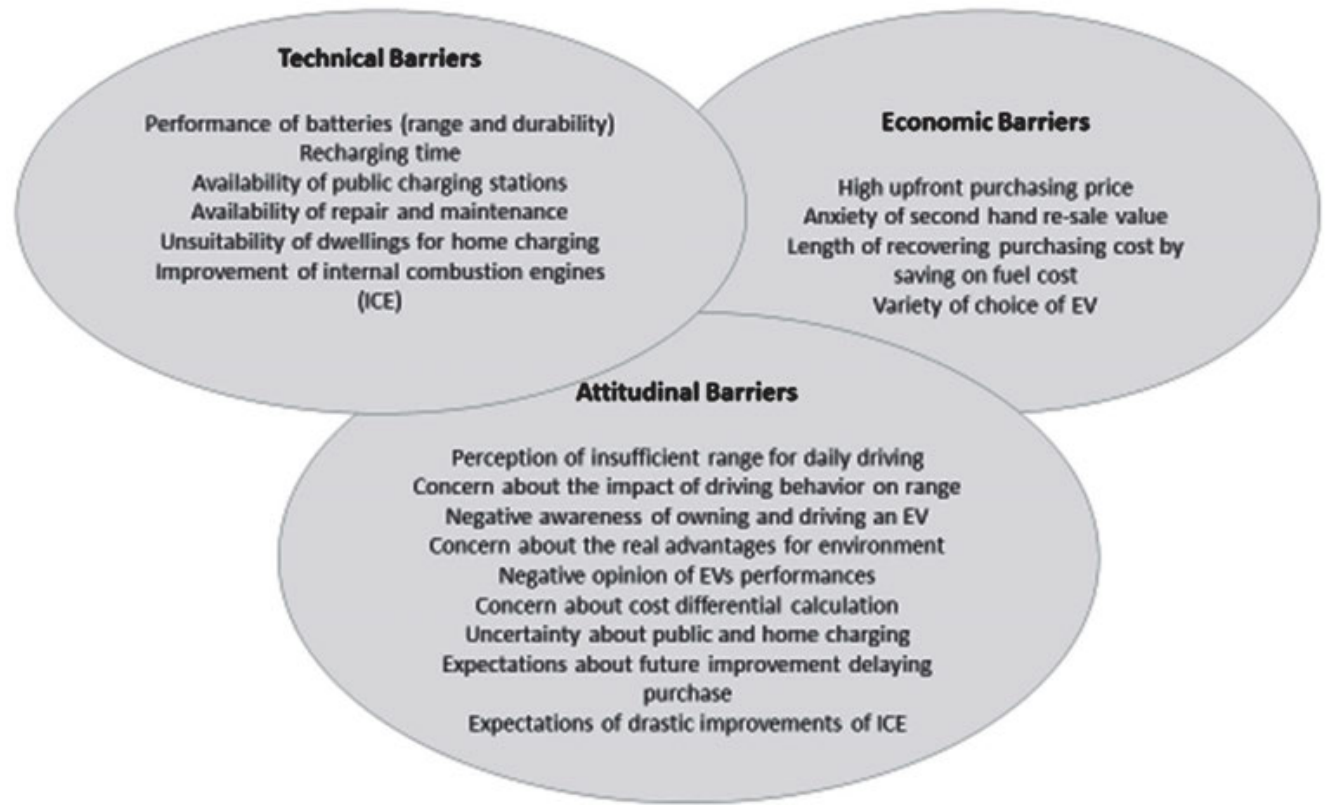

Source: Adapted from Berkeley et al. (2017.

Figure 14. Barriers to EVs adoption

Benoît Potier, CEO of Air Liquide and co-chairman of the Hydrogen Council calls it "essential vector of the energy transition" ${ }^{24}$. The hydrogen molecule is particularly energetic, three times more than gasoline. In addition, hydrogen, when produced from renewable resources, is considered non-polluting and has the advantage of being faster to recharge. It takes a recharge time of about $3 \mathrm{~min}$ utes in a filling station. Hydrogen is also considered a sustainable way to store energy, which is not possible with electricity.

But similarly, to the full battery option, there are still big problems to resolve: the production of hydrogen is both polluting and expensive. To date, $96 \%$ of hydrogen is produced from fossil fuels (oil, natural gas and coal) because this method is the most profitable. "Carbon-free" technologies are ready to go on the market, but they have to move to significant production scales to reduce costs.

The deployment of a hydrogen sector requires relatively heavy investments, both for the production, distribution and storage of hydrogen. The Hydrogen

${ }^{24}$ Le Figaro, 14/12/2017. 
Council estimates these investment needs at between $\$ 20$ billion and $\$ 25$ billion annually, or about $\$ 280$ billion by 2030 . This is worth pinpointing that this is well below the $\$ 650$ billion annual investment in oil and gas!

In April 2020, Daimler Benz decided to withdraw from the fuel cell for passenger car market after 30 years of research-development. This is officially due to its incapacity to reduce the cost to compete will full battery electric vehicles, in particular because the high cost of maintaining hydrogen under pressure at its liquefaction temperature. According to Daimler Benz and also Volkswagen, this is downgrading the energy efficiency of a fuel cell electric car to $25 \%$ to $35 \%$ against $70 \%$ to $90 \%$ for a battery electric $\mathrm{car}^{25}$.

As for conventional engines, they have probably not said their last word! Is a low-energy solution with a hybrid technology with a consumption of 1.3 to 2 liters per $100 \mathrm{~km}$ able to delay the emergence of the electric battery car by a few decades and thus give time for a solution to emerge? to hydrogen? It has been already mentioned that prototypes such as the Renault Eolab achieve very low fuel consumption levels.

It is clear with the emblematic example of the automobile, innovation remains a complex process, often if not always unpredictable, impossible to manage ex abrupto in general. In the traditional manufacturing industries, well established on their technology, many factors block or at least hinder the emergence of alternative technologies ${ }^{26}$, in particular because, over time, industrial players have accumulated knowledge and know-how that shape their thinking patterns. They also accumulated very productive fixed investments. We then speak of path dependency. Would this dependency be erased by new breakthrough incentives?

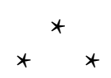

Since this paper has been prepared, the Covid-19 pandemic crisis emerged and forced more than half of the world's total population to severe containment and an almost total halt to global auto production. In Europe and North America, vehicle sales have dropped sharply, and production has come to a nearly complete stop for several weeks. Obviously, when the crisis will be over, production and sales will restart. But nobody could know when and to what extent. Nobody could know if the industry organization will not be completely disrupted and moved to a deep restructuring. And indeed nobody could predict what the consumers will buy, in particular if they will shift to electric vehicles. It is highly possible that the impoverishment of many potential buyers would push them towards very affordable models! The dramatic fall of oil prices would also be a negative factor.

25 Challenge, 24/04/2020.

26 Bye, P., Chanaron J.J., (1995), Technology Trajectories and Strategies, International Journal of Technology Management, 10, 1, pp. 45-66. 
Recently, the Center for Automotive Research (CAR) in Ann Arbor (USA) published the following questions that automakers and suppliers need urgently to address on the supply side:

- How does the automotive industry adjust its traditional business practices post-crisis?

- How do companies manage and monitor workers' health conditions?

- Are changes needed to current inventory management?

- How do companies evaluate and respond to supply chain risks and disruptions?

- Does this crisis push the need for companies to reset the production process?

- How do companies prepare to avoid another crisis impact on their business?

Other questions need to be addressed at the demand side:

- How do consumers adjust their preferences post-crisis?

- How do users change their mobility behavior after the crisis?

- Would the demand structure remain similar?

- Which market segments will emerge positively?

Due to the Covid-19 pandemic, the future of alternative technological options to internal combustion-based automobile (and trucks) is obviously at stake $^{27}$. With the dramatic drop in financial resources for both manufacturers and customers, many decisions would certainly be postponed for quite a long time, even if most economists predict a strong recovery when the epidemic will be stopped. As it has been underlined by most observers and analysts during this period, the post-crisis will be different from the pre-crisis situation!

\section{Literature:}

- Aguire B., Eisenhardt L., Lim C., Nelson B., Norring A., Slowik P., Tu N ., (2012). Lifecycle Analysis Comparison of a Battery Electric Vehicle and a Conventional Gasoline Vehicle, California Air Resources Board, June.

- Ahmed P. K., (1998), Benchmarking innovation best practice, Benchmarking for Quality Management \& Technology, 5, 1; pp. 45-56.

- Alexander M., Davis M., (2013), Total Cost of Ownership Model for Current Plug-In Electric Vehicles, EPRI Technical Report.

- De Banville, E., Chanaron, J.J., (1985), Le système automobile français : de la sous-traitance au partenariat ? Eléments pour une problématique, CPE. Etude, $n^{\circ} 56$, mai.

27 Challenges, 01/05/2020. 
- $\quad$ Bardou, J.P., Chanaron, J.J., Laux, J., Fridenson, P., (1977), La Révolution Automobile, Paris, Albin Michel, coll. l'Aventure Humaine.

- Bardou, J.P., Chanaron, J.J., Laux, J., Fridenson, P., (1982), The Automobile Revolution, The Impact of an Industry, University of North Carolina Press, Chapell Hill.

- Berkeley, N., Bailey, D., Jones, A., Jarvis, D., (2017), Assessing the transition towards Battery Electric Vehicles: A Multi-Level Perspective on drivers of, and barriers to, take up, Transportation Research Part A, 106, pp 320-332.

- Bloomberg New Energy Finance (2016), Electric vehicles to be 35\% of global new car sales by 2040, New York-London, 25/02.

- Burgelman, R.A., Christensen, C.M., Wheelwright, S.C., (2004), Management of Technology and Innovation, Irwin Publishers, Chicago.

- Bye, P., Chanaron J.J., (1995), Technology Trajectories and Strategies, International Journal of Technology Management, 10, 1, pp. 45-66.

- Cai Z., O.X., Zhang Q., Zhang X., (2012), Full lifetime cost analysis of battery, plug-in hybrid and FCEVs in China in the near future, Frontiers in Energy, 6, 2, pp. 107-111.

- Carayannis, E.G., Ziemnowicz, C., (2007), Rediscovering Schumpeter: creative destruction evolving into" Mode 3", Palgrave Macmillan, New York.

- Chanaron, J.J. (1973), L'innovation dans la construction automobile, Thèse de doctorat, IPEPS/IREP, Grenoble, novembre.

- Chanaron, J.J., (1977), Le modèle systémique conceptuel de l'innovation de E. Mottur, in Nicolon, A., Le Véhicule Electrique, Paris Editions du CNRS, Coll. Energie et Société, pp. 107-117.

- Chanaron, J.J., (1994), Perspectives de la voiture électrique : les leçons de l'histoire, Revue de l'Energie, numéro spécial Energie, Transports, Environnement, $\mathrm{n}^{\circ} 463$, novembre, pp. 627-635.

- Chanaron, J.J., (1998), Automobiles: a static technology, a « wait-and-see » industry?, International Journal of Technology Management, Vol. 16, $\mathrm{n}^{\circ} 7$, pp.595-630.

- Chanaron J.J., (2013), Innovation Valuation: Guesswork or Formalized Framework? A Literature Review, in Akhilesh, K.B., (2013), Emerging Dimensions of Technology Management, Springer India, pp. 17-33.

- Chanaron, J.J., (2014), Towards an Operational Framework in Forecasting Breakthrough Innovation: The Case of the Clean Automobile, International Journal of Electric and Hybrid Vehicle, Vol. 6, N², pp. 87-107.

- Chanaron J.J., (2014), Recent Advances on the Design of Batteries and Fuel Cells for Automobiles, Recent Patents on Mechanical Engineering, 7, 2, pp. 113-121.

- Chanaron, J.J., Metcalfe, S.M., (2007), Schumpeter's Innovation Theory, in Carayannis, E., Ziemnowicz C., (2007). Re-Discovering Schumpeter: Creative Destruction Evolving into 'Mode 3', MacMillan-Palgrave, New York, pp. 52-67. 
- Chanaron J.J., Teske J., (2007), The hybrid car: a temporary step, The International Journal of Automobile Technology \& Management, Vol. 7, n⿳4十, pp. 268-288.

- Dougherty, D., Hardy, C. (1996), Sustained product innovation in large mature organizations: Overcoming innovation-to-organization problems, Academy of Management Journal, 39, 5, pp. 1120-1153.

- Jantsch E., (1967), Technological Forecasting in Perspective? La prévision technologique, Paris, OECD-OCDE, downloaded from https://www.echosdunet.net/dossier/diact.

- Jun M., Di Muro (2013). Holistic Methodology to Analyze EV Business Models, International Journal of Innovation, Management and Technology, 4, 2, pp. 259-264.

- McCullough R., (2012). Are Electric Vehicles Actually Cost-Effective, Electricity Policy.com, pp. 1-10.

- Pearre, N.S., Kempton, W., Guensler, R.L., Elango, V.V., (2011), Electric vehicles: How much range is required for a day's driving?, Transportation Research Part C, 19, pp. 1171-1184.

- Poupon, L., Philipps-Bertin, C., Bobillier-Chaumont, M.E., Kalampalikis, N. (2017), L'acceptation de la voiture électrique : un agent transformateur des pratiques socio-domestiques, Activites, 14, 2, pp. 1-25.

- Schumpeter, J.A., (1911), The Theory of Economic Development: An Inquiry Into Profits, Capital, Credit, Interest, and the Business Cycle, Harvard University Press, Cambridge, 1934 edition.

- Tamor, M.A., Gearhart, C., Soto, C., (2013), A statistical approach to estimating acceptance of electric vehicles and electrification of personal transportation, Transportation Research Part C, 26, pp. 125-134.

- Tamor, M.A., Moraal, P.E., Reprogle, B., Milacic, M., (2015), Rapid estimation of electric vehicle acceptance using a general description of driving patterns, Transportation Research Part C, 51, pp. 136-148.

- Tidd, J., Bessant, J., Pavitt, K., (1997), Managing Innovation: Integrating Technological, Market and Organizational Change, John Wiley \& Sons, London, 3rd edition, 2005.

- Williams E., (2008), Plug-in and Regular Hybrids: A National and Regional Comparison of Costs and CO2 Emissions, Climate Change Policy Partnership, Duke University, November.

- Yin R, (2008), Case study research: Design and methods (3rd ed.). Beverly Hills, CA: Sage Publishing. 


\section{IZAZOVI RADIKALNIM INOVACIJAMA VODEĆA TEHNOLOGIJA AUTOMOBILA BUDUĆNOSTI? Drugi deo}

Sažetak: Drugi članak o automobilu za budućnost, istražuje razne mogućnosti za uspešno inovativno rešenje. Predložen je analitički model za inovacije. Ova nova mreža za analizu omogućava procenu potencijala za pojavu novih proizvoda, novih usluga, novih procesa ili novih organizacija, pod pretpostavkom da istovremeno moraju biti ispunjena četiri uslova (istovremeno, na istom mestu): „Naučno i tehnički moguće“; „Industrijski izvodljivo“; „Komercijalno prodajno“; $i$ „Politički, socijalno i kulturno prihvatljivo». Šest ključnih faktora uspeha su sledeći: autonomija ili domet vožnje; tehnološka jednostavnost; ukupni troškovi, odnosno troškovi kupovine i troškovi upotrebe; dostupnost i sigurnost snabdevanja, u vremenu i prostoru primarne energije; Bezbednost i pouzdanost; Vremenski opseg primene inovacija. Specifični uslovi automobilske industrije se detaljno analiziraju i razmatraju, kao i opšta ekonomska i politička pitanja koja pozitivno ili negativno utiču na uvođenje novih inovativnih automobila.

Ključne reči: inovacije, automobile, električno vozilo, upravljanje tehnologijom 